\title{
The Management of Household Waste Based on Waste Bank to Increase Community Income in Surakarta City
}

\author{
Irsyadul Ibad*, LV Ratna Devi S \\ Faculty of Social and Political Sciences, Universitas Sebelas Maret, Indonesia \\ *irsyadulibad@staff.uns.ac.id
}

\begin{abstract}
This research is conducted to understand and analyze the management of household waste based on waste bank to increase community income in Surakarta city. A case study used with a purposive sampling of the Rejeki Lancar waste bank, which is a productive waste bank and is able to produce creative products from household waste recycling. The results show that the management of household waste that could increase community income began with the stages of establishing a waste bank, socializing the waste bank, technical training in waste management, implementing a waste bank system, and marketing creative products. The mechanism of the waste bank system itself consists of sorting waste, depositing waste, weighing waste, recording, and transporting waste. Constraints encountered are the lack of integration of the role of the government and the private sector in household waste management based on waste bank in terms of socialization, technical training, facilities and infrastructures of the waste bank, and marketing of creative waste recycling products. Therefore, government and private sector intervention is needed to support the running of household waste management based on waste bank and to increase the economic value of waste management in the community.
\end{abstract}

Keywords: Creative Waste Products, Community Income, Household Waste, Waste Bank, Management

\section{INTRODUCTION}

Surakarta City is an autonomous region under the Province of Central Java. This city is one of the developed cities in terms of regional development. The development of the city will be followed by an increase in population, which will also be followed by social and environmental problems. One of the environmental problems that arises is the problem of waste (Alkadri et al., 1999). Waste is solid waste consisting of organic and inorganic waste, generally originating from domestic (domestic) activities, industrial activities, office activities, and others (Djajanagara, 2004; Krisnandar, 2013).

Based on the data integration book of the Surakarta city environmental service as of February 1, 2018, the volume of waste in 2017 averaged 106,279 tons, of which 58\% were household waste. This number is indicated to continue to increase in the following years. This household waste requires management that must involve the community as a source of waste generation.

Community based waste management is very important, because the activity is carried out by the community members themselves. They make decisions related to 
their own lives. It will be more effective if it is adjusted to local needs and their priorities and capacities (Sutandyo-Buchholz, 2005 in Koesrimardiyati, 2011). Kastaman (2004) in Koesrimardiyati (2011) defined communitybased waste management as an approach to waste management based on active community participation. Koesrimardiyati (2011) stated that community-based waste management activities can continue if there is a change in the behavior of residents who manage their waste independently, accompanied by community organizing that is centered on women at the community level, one of which is the hamlet. According to Singhirunnusorn et al. (2012), changes in the way people think about managing household waste to reduce waste at the source through citizen participation must be integrated into the community-based waste bank project.

According to Aryeti (2011), the waste bank is a place to store waste that has been sorted by type of waste. The way bank work is generally same as the other banks, there are financial statements, record keeping and management. If a commercial bank receives money, the waste bank receives waste money. Separation of household waste that falls into the category of organic waste can be composted while non-organic household waste is combined with a waste bank for recycling and can be used as economical source (Jumar et al. 2014). Waste will have an economic value in sufficient quantities as economic goods, both as raw material (recycling) and as a commodity trade. If the community as a producer of waste carries out a role in waste management, for example 3R; then the place and marketing the trash needs to be a place. This is where the importance of the waste bank can be seen as a means for the community to save, improve socialeconomics, and empower the community in waste management. (Suryani, 2014).

The innovation of processing waste under the waste bank program becomes an innovation at the grassroots level that can increase the community income (Winarso and Larasati, 2011). Solution to the problem can be done through the involvement of housewives. Every household is involved in waste management, at least in managing its own household waste. If examined more than that, it is very beneficial to household income (Siska Maya, Sugeng Haryono, Umi Kholisya, 2017). Managing household waste is a business opportunity that benefits while enhancing environmental cleanliness (Sidarto, 2010). Based on the background that mentioned above, the objective of the research is to understand and analyze the management of household waste based on waste bank to increase community income in Surakarta city.

\section{METHOD}

In accordance with the objective of the research, namely to understand the management of household waste based on waste bank to increase community income, researchers used a qualitative approach, which is an approach that aims to understand a social phenomenon, as a research approach (Creswell, 1994). This study used a qualitative approach because the main concern of the researcher is directed at the process and meaning of human social interactions in real life. Researchers feel the need to explore and further explain the phenomenon of community-based household waste management in the Rejeki Lancar waste bank.

This research was conducted by the case study method, in which the researcher explored a case that was bound by time and activity which could be a program, event, process, institution, or social group and collected detailed information using various data collection procedures over a certain period (Creswell, 2010). This method is appropriate for this study because researchers cannot manipulate the behavior of the research objects involved under study (Yin, 2003). In addition, Yin also mentioned that this method is also used to understand cases that cannot be separated from the context, the activities of Kedunglumbu residents in waste management are bound to the context of waste management itself. 
This research was conducted at the Rejeki Lancar waste bank, Kedunglumbu Urban Village, Pasar Kliwon Subdistrict, Surakarta City, in accordance with the research objective. This location was chosen under the consideration: 1) The existence of household waste management activities carried out in the Kedunglumbu Urban Village through a waste bank; 2) The existence of creative products from household waste recycling carried out by housewives through a waste bank in Kedunglumbu Urban Village that able to increase community income.

Considering the information needed to understand the sustainability of household waste management in the Kedunglumbu, the method of determining the informant used is purposive sampling, the informant is intentionally determined by the researcher based on certain criteria according to the objective to be achieved. The criteria used in determining the informants in this study are as follows: 1) The informant is an official resident of the Kedunglumbu sub-district who served as the administrator of the Rejeki Lancar waste bank for at least one year; 2) The informant is an official resident of the Kedunglumbu urban village who served as one of the Neighborhood/Hamlet units for at least one year. Therefore, there are eight informants in this study consisting of: 1) Six board members of the Rejeki Lancar waste bank consisting of the Chairperson, Secretary, Treasurer, Sorting Section, Weighing Section, and Public Relations Section; 2) One urban village official who serves as the head of the Neighborhood/Hamlet; 3) One community member, a housewife, manages household waste.

Data Collection Techniques used in this study include: 1) Interview: the interview technique used was in-depth interviews to ask informants' views about certain things in order to answer research question. Interviews were conducted face to face with informants, equipped with voice recorders. Furthermore, the interview is conducted openly, with questions that refer to interview guidelines that have been prepared by the researcher. Researchers conducted further interviews to complete the data that was felt to be still lacking. For the purposes of research validity, member checking is conducted so that the informant can clarify the results of interviews conducted by researchers; 2) Observation: the researcher conducted direct nonparticipant observation at the observed study site. After that, systematic recording of events in the field is carried out. Researchers visited waste bank, waste warehouse, informant houses and observed household waste processing activities carried out by the informant. The researcher also observed the physical condition and environment of the informant's residence; 3) Document Study: the document studies are carried out through various media, such as state documents, books, journals, papers, newspapers and articles on the website to obtain a theoretical and practical picture of community-based household waste management activities making it easier for researchers to understand the research context.

This study used Interactive Model of Analysis. According to Miles and Huberman (2009) in this model three components of analysis, namely data reduction, data presentation and conclusion drawing, are carried out in an interactive form by the process of data collecting as a cycle. At this stage, the researcher was given the initial code according to the data collection method used, namely for the interview the name "int" is used, for observation the name "obs" is used, and for the documentation the name "doc" is used. The interview record was copied into a transcript containing word for word that is exactly the same as the recording. Furthermore, the informant's data transcript was written in full and grouped according to a specific format, using the initials of the informant's name and position. The same thing is done for field notes (field notes) which are the result of observation. Field notes are organized into a format with certain titles such as date, time, place, informant, description of the event. Next, the 
data from the study document were organized into a format to support data from interviews and observations. In the data reduction stage, the entire transcript was marked to find key topics and makes coding and classification easier. Furthermore, it was grouped into specific themes to suit the research objectives. At the data presentation stage, the results of the data coding were then interpreted. In interpreting, the researcher must hold on to the coherence between the results of the coding data and the purpose of the research. At the stage of drawing conclusions, researchers began to make initial conclusions based on data that has been presented. Conclusions were drawn by looking for patterns by comparing the results of data processing with patterns derived from related theories or literature.

The validity and reliability of the data was carried out using two techniques, including: a). Triangulation, conducted by researchers using more than one theory and using several methods, namely interviews with informants, direct observation, and document studies relating to household waste management activities. at the research location; b). Member checking was done by returning to the research location to check the results of the interview transcript as well as its interpretation to the research informant to ensure that the interpretation prepared by the researcher is correct.

\section{RESULT AND DISCUSSION Establishing a Waste Bank}

The early initiation of waste bankbased household waste management in the Kedunglumbu began with the Surakarta Mayor's instructions on environmental management. An act of handling dengue fever that was spreading there. The follow up of the instruction was the formation of the management of the waste bank. The management of the waste bank program in the Kedunglumbu was formed through a joint meeting with urban village officials, Consultative Agency, Community Resilience Institution, Hamlet Chairperson, and Neighborhood Chairperson. The management of the waste bank was the coordination between urban village officials and the residents elected in the management. Management of Rejeki Lancar Waste Bank consists of: 1) Chairperson of the waste Bank, whose job is as coordinator of the management of the waste bank; 2) Secretary (2 people), whose job is to record the entry and exit of waste from the depositors (waste customers) and waste collectors; 3 ) Treasurer ( 2 people), in charge of saving money from the sale of waste from the depositors (waste customers) and waste collectors; 4) Sorting Section (5 people), in charge of controlling the results of sorting waste that has been deposited to the waste bank; 5) Weighing Section (5 people), weighing the waste delivered by the community to the bank, 6) Public Relations Section (3 people), whose job is as customer service, disseminating information about waste banks to the general public, coordinating and selling waste and recycling products.

The Rejeki Lancar waste bank is located in one of the rooms in the urban village hall. Due to limited space, household waste recycling can be done by housewives in their respective homes so that the waste bank space in the Urban Village office becomes a showroom of household waste products. The consumers can go directly there to buy creative processed refined products. In addition, as a support for the running of a waste bank, the Official of Urban Village provides an empty space that functions as non-organic waste warehouse which has been sorted and is waiting for collectors to collect it. The warehouse is located in one of the former rooms at Kedunglumbu elementary school.

Waste banks can be managed by the urban village level government, hamlet or other organizations such as youth organizations, Family Welfare Movement groups and can also be managed by individuals who care about waste management. Parties related to the waste bank include community members (as waste customers), urban village/hamlet heads/ program managers, collectors (waste buyers), 
waste management operational operators, buyers of waste recycling and others. (Marwati, 2013).

\section{Early Socialization}

To promote community involvement in managing waste require campaigns about waste disposal and recycling behavior so as not to have an adverse effect on the community (Piyapong Janmaimool, 2017). Initial socialization was carried out to provide an introduction and basic knowledge about waste banks to the public. Material presented includes: 1) Waste Bank as a national program. Law number 18 of 2008 mandates waste management with the principle of 3-R (reduce, reuse, recycle). The government invites the community to reduce, reuse, and recycle waste. The government make the waste bank a 3-R implementation strategy; 2) General explanation of the understanding of waste banks. Waste bank is a system that focuses its activities on managing household waste collectively; 3) Explanation of waste management flow in the waste bank system.

The mechanism of work of a waste bank starts from sorting, depositing, weighing, recording, and transporting; 4) Distribution of waste management results. Proceeds from the sale of waste do not fully belong to the customer. Some is set aside for operational costs for waste and the development of waste bank in the future. The profit-sharing percentage is determined through an agreement between the customer and the manager of the waste bank. In the Rejeki Lancar waste bank, the percentage of the proceeds from the sale of waste is not determined by the amount of the percentage and is voluntary. The customer may give any amount from the sale of the waste.

This socialization was carried out at the urban village level so that it was possible to gather citizens in a broad scope. The target of this activity were housewives as the main actors in household scale waste management and also decision makers such as Neighborhood heads, Hamlet heads, Urban Village Officials and all Urban Village
Leaders or Environmental Cadres. The socialization of the waste bank was carried out by the Chairperson of the Rejeki Lancar Waste Bank who is also the chair of the SME Center of Danukusuman. It showed that there was no active role of the government in socializing waste banks.

\section{Technical Training}

The technical training aimed to provide a detailed explanation to the public regarding the procedures for implementing the waste bank system. The training speaker was the Chair of the Rejeki Lancar Waste Bank who was also the chair of the SME's Center of Danukusuman. It also showed that there was no active role of the government in providing training on waste management. This training was conducted in a small scope, namely at the Neighborhood/Hamlet level. This technical training was attended by at least $50 \%$ of local Neighborhood/Hamlet residents. These activities include: 1) Explanation of the waste bank system. In order for the waste bank system to run, there are several things that must be in place, among others: waste that has been sorted from home, plastic collection facilities, management of the waste bank, agreed waste collection schedule, recording system, collaboration with collectors, and agreement on the collection schedule waste by collectors, 2) The mechanism of work of the waste bank. The working mechanism of the waste bank consists of sorting, depositing, weighing, recording, and transporting; 3). Recycle : the community was given training to recycle household inorganic waste in the form of paper, plastic, bottles, etc. to be used as creative products. This training was aimed at making the community get economic benefits so that waste is no longer considered a useless item; 4) Regulations: the regulations that have been mutually agreed upon in the Rejeki Lancar waste bank: a) the deposited waste must be properly sorted, bag I contains plastic waste, bag II contains paper waste, bag III contains metal waste, bag IV contains glass waste; b) The results of the economic 
value of waste from the sale of waste to collectors and creative products that are deposited to the waste bank will be deducted voluntarily and used for operational costs of the waste bank; c) Waste deposits will only be served every Sunday of the second and fourth week of the month at 15:00 to 17:00; d) Organic waste is temporarily managed by each household by empowering the fathers.

\section{Implementation of the Waste Bank System}

The mechanism of the Rejeki Lancar waste bank system consists of several stages of activities including:

1. Household Waste Sorting. Optimization of waste management will succeed if it starts with the level of sorting (Suwarno, 2013). Household waste segregation is carried out in each household. The sorted waste is only inorganic waste in the form of plastic, paper, glass or metal waste. Organic waste which is left over from food or drinks will be made for compost by empowering the fathers in each household. Residents who are not willing to process organic waste can be disposed of at the Waste Dump to be transported to the Final Waste Disposal Site

2. Depositing Waste to the Waste Bank. The deposited waste is non-organic waste which has been sorted according to its type such as paper, plastic, bottles, cans, iron, aluminum and others in separate bags. This is useful to facilitate the weighing and recording of waste from the community members. Waste deposit cannot be done at any time but must adjust to the agreed waste deposit schedule

3. Waste Weighing. Waste that has been deposited to the waste bank will then be weighed. The weight of waste that can be deposited must be in accordance with the previous agreement, which is at least one kilogram.

4. Waste Recording. The clerk will record the type and weight of the waste after weighing. The measurement results will be converted into rupiah value which is then written in a savings book. Savings can be taken every three months but usually the customer will take the savings every Eid holiday. The waste recording system includes several things including: a) Administrator: Book for customer registration. Contains a list of customer data and their information.

Table 1. Customer Registration Book

\begin{tabular}{l}
\hline $\begin{array}{c}\text { Customer } \\
\text { Registration Nome Address } \\
\text { Number } *\end{array}$ \\
$\begin{array}{c}\text { Number of } \\
\text { people/ } \\
\text { Family }\end{array}$ \\
\hline 1 \\
* Customer Registration Number: Name of Urban \\
Village_Abbreviation of Waste Bank \\
Name_Neighborhood_Hamlet_Serial Number \\
Source: Secondary data, 2019
\end{tabular}

Table 2. General Ledger of Administration

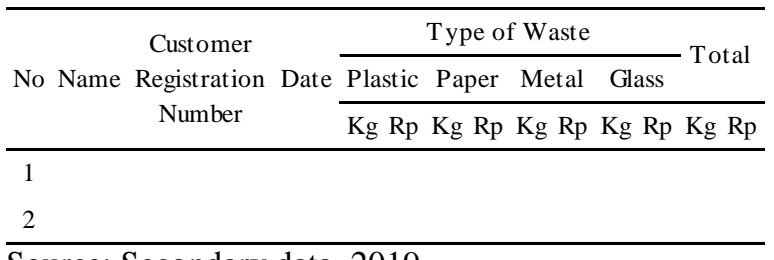

Source: Secondary data, 2019

The Waste Bank Administration Ledger. Loading data on waste weight, recapitulation of waste sales value, total waste weight, and waste sales value; b) Customer: Customer savings book. This book includes the credit, debit and balance columns to record the transactions made. There are two types of forms that contain overall customer savings data and forms that contain periodic savings data at each sale.

Table 3. Customer Savings Book

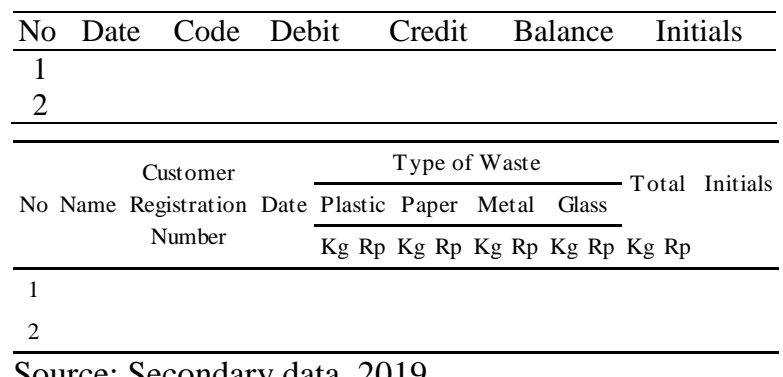

Source: Secondary data, 2019 
Table 4. Waste Code List

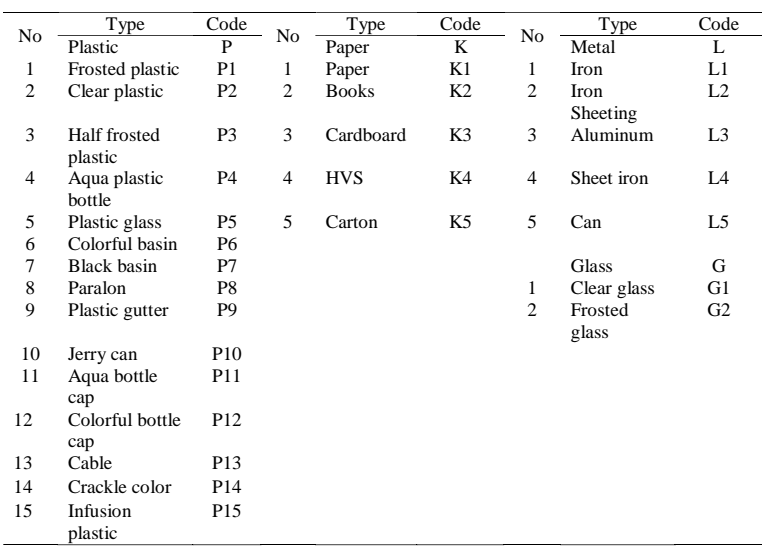

Source: Secondary data, 2019

Savings flow in waste bank is as follows:

(i) Every customer register with the secretary, the secretary will record the customer's name and each member will be given an official savings book. Customers who want to save waste must come to the waste bank warehouse or local neighborhood leader who has been appointed by bringing in sorted waste according to its type such as plastic, paper, metal, glass, and others in separate bags, (ii) Waste to be saved must be clean and dry. The teller staff will weigh, record, label and put the trash in the space provided. Customers who have saved money can withdraw their money according to the agreed terms or every 3 months can take the money. While the saving schedule is determined by the manager, (iii) Recording in the savings book will be the benchmark of how much money has been collected by each customer, while the waste bank provides a price based on the market price of the waste collector. The funds collected will be managed by the treasurer

5. Waste transporting. Waste transporting is carried out either independently or collectively. The customer can directly deposit the waste into the waste bank warehouse or deposit it to the appointed local environment leader and from there it will be transported to the waste bank warehouse. Due to the large volume of waste, the transportation of collectives from each of the environmental leaders is constrained. There is no special fleet designated as a means of transporting waste, so the local environment leader must voluntarily go back and forth to transport waste. The operational conditions of waste collection and transport activities are currently not running optimally due to the lack of waste storage facilities and the number of waste transport fleets (Wiraatmaja, I Wayan, \& Ida, 2012). The number of waste transport fleets is not proportional to the volume of waste produced (Wiraatmaja, I Wayan, \& Ida, 2012).

\section{Marketing of Waste Creative Products}

Processing of non-organic waste is generally carried out by recycling plastic, metal and paper into items that can be remade as the original form or converted into high-value and beautiful works of art. For households that have not been able to produce works of art from non-organic waste, can sell this type of waste to scavengers or collectors because non-organic waste has a sale value and can be used for the needs of the recycling industry. (Amantya Koesrimardiyati, 2011). Not all residents are able to process waste into creative products so that the waste they collect will be sold to collectors, while for those who are able to process waste, the waste recycling process is carried out in their respective homes and then deposited in the waste bank to be marketed.

Recycling is defined as a waste treatment process that can produce useful products again (Department of Public Works, 1990). The purpose of recycling as an alternative to waste management is to create sustainable self-sufficient urban communities, which are based on local production of local resources for local consumption (Gandy, 1994). There are three levels of recycling (Cointreau et al., 1985), namely: 1) After sorting and washing, waste can be directly reused, repaired, or remanufactured; 2) Waste is sorted, washed, processed, and recycled into new materials 
or new products; 3) Waste is converted into material that differs from its original form or becomes energy.

Waste management is carried out by residents in the Rejeki Lancar waste bank in the form of recycling non-organic household waste into handicraft products. These products include flower vases and colorful flowers, woman's bags, wallets, lamp shades, key chains, and other crafts such as the Solo Batik Carnival mat costume made from packaging waste. These creative products are promoted through the waste bank office in the Urban village, then at the SME Center of Danukusuman office, as well as at the Ngarsopuro night market located in the center of Surakarta city which is held every Saturday evening. The marketing network for the processed refined creative products is the result of the networking of the Rejeki Lancar waste bank manager with the Surakarta City Cooperative and SME Office. In addition, the marketing of creative products is also carried out by participating in creative product exhibitions and through creative waste product competitions. Even so, the marketing of creative products still faces obstacles, namely the low awareness of the public to use creative products from recycled waste. They feel that recycled products are not worth buying and using. The development of the waste bank will be more integrated with the support of the local government and the local businessmen to be very important. Basically, the intervention of the local government is needed to support the operation and the role of the local company / entrepreneur is needed to increase the economic value of waste management in the community. (Donna Asteria \& Heru Heruman, 2016).

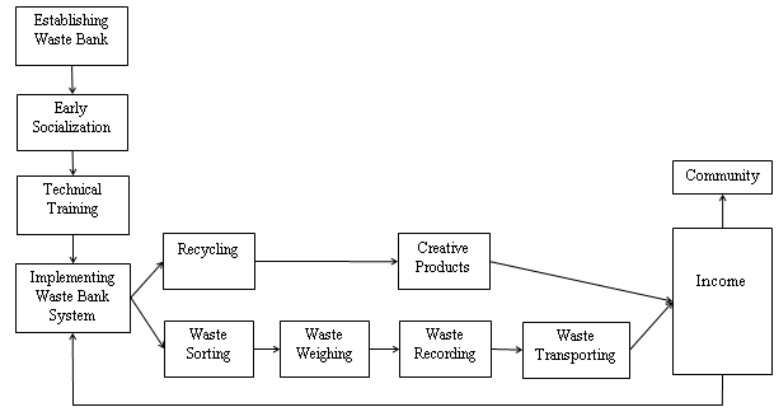

Figure 1: Flowchart of Waste Bank System to increase community income

\section{Conclusion}

Waste bank-based household waste management to increase community income in the city of Surakarta begins with the stages of establishing a waste bank, socializing a waste bank, technical training in waste management, implementing a waste bank system, and marketing creative products. The mechanism of the waste bank system itself consists of sorting waste, depositing waste, weighing waste, recording, and transporting waste. The obstacles encountered were the lack of integration of the role of the government and the private sector in household waste management based on waste banks, related to support in socialization, technical training, facilities and infrastructure for waste banks, and marketing networks for creative waste recycling products. Therefore, government and private sector intervention is needed to support the smooth management of household waste based on waste banks and increase the economic value of waste management in the community. Based on the conclusion above, further research on the model of marketing management of the creative waste product is needed to be conducted. Therefore, the role of government and private sector need to be addressed to support the management of household waste based on waste bank to increase the community income. 


\section{REFERENCES}

Alkadri, Muchdie, Suhandoyo. (1999). Tiga Pilar Pengembangan Wilayah, Pusat Pengkajian Kebijakan Teknologi Pengembangan Wilayah-BPPT, Jakarta.

Artiningsih, AK. (2008). Peran Serta Masyarakat dalam Pengelolaan Sampah Rumah Tangga (Studi kasus di Sampangan dan Jombang, Kota Semarang). Tesis Program Studi Ilmu Lingkungan. Universitas Dipenogoro Semarang.

Aryeti. (2011) Peningkatan Peranserta Masyarakat Melalui Gerakan Menabung pada Bank Sampah di Kelurahan Babakan Surabaya, Kiaracondong Bandung. Jurnal Permukiman, 6 (1 ), 40-46.

Asteria, Dona \& Heru Heruman. (2016). Bank Sampah Sebagai Alternatif Strategi Pengelolaan Sampah Berbasis Masyarakat Di Tasikmalaya, Jurnal Manusia dan Lingkungan. Fakultas Ilmu Sosial dan Ilmu Politik. Universitas Indonesia. Depok

Creswell, J.W. (2010) Research Design: Pendekatan Kualitatif, Kuantitatif, dan Mixed. Yogyakarta: Pustaka Pelajar.

Djajanagara, S. (2004), Kajian Pengelolaan Sampah di Jawa Barat, Badan Penelitian dan Pengembangan Daerah Provinsi Jawa Barat, Bandung.

Jumar, dkk. (2014). Strategi Pengelolaan Sampah Rumah Tangga Di Urban village Lok Bahu Kecamatan Sungai Kunjang Kota Samarinda. eJournal Administrative Reform. 2(1), 771-782.

Koesrimardiyati, (2011). Keberlanjutan Pengelolaan Sampah Berbasis Masyarakat (Studi Kasus Peran Perempuan dalam Kegiatan Pengelolaan Sampah di RW 013 Cipinang Melayu Jakarta Timur) (tesis). Program Magister Ilmu Lingkungan, Universitas Indonesia.

Krisnandar, H. (2013). Pengelolaan Sampah Rumah Tangga Secara Mandiri Berbasis Masyarakat (Studi Kasus di Rukun Warga 01 Kelurahan
Parakannyasag Kecamatan Indihiang Kota Tasikmalaya). Jurnal Universitas Siliwangi Tasikmalaya.

Maya, Siska., Haryono, Sugeng., \& Kholisya, Umi (2017). Pemberdayaan Masyarakat Melalui Pengelolaan Sampah Menjadi Nilai Ekonomis dan Pembentukan Bank Sampah di Kelurahan Tanjung Barat. Proceeding of Community Development. 1, 157161.

Miles, Matthew B. \& A. Michael Huberman. 2009. Analisis Data Kualitatif. Jakarta: UI-Press.

Piyapong Janmaimool, (2017). Application of Protection Motivation Theory to Investigate Sustainable Waste Management. Behaviors Sustainability. 9(7), 1079.

Sidarto, (2010). Analisis Usaha Proses Pengelolaan Sampah Rumah Tangga Dengan Pendekatan Cost and Benefit Ratio Guna Menunjang Kebersihan Lingkungan. Jurnal Teknologi, 3 (2)

Singhirunnusorn, W., Donlakorn, K., \& Kaewhanin, W., (2012). Household Recycling Behaviours and Attitudes toward Waste Bank Project: Mahasarakham Municipality. Journal of Asia Behavioural Studies, 2(6),3547.

Suryani, Anih Sri, (2014), Peran Bank Sampah dalam Efektivitas Pengelolaan Sampah (Studi Kasus Bank Sampah Malang). Pusat Pengkajian, Pengolahan Data dan Informasi DPR RI.

Winarso, H.\& Larasati, A.. (2011.) Dari Sampah Menjadi Upah: Inovasi Pengolahan Sampah di Tingkat Akar Rumput Kasus Program Bank Sampah "Sendu" di Urban village Pasar Minggu Jakarta Selatan. Jurnal Manusia dan Lingkungan, 18(1), 4359.

Yin, R. (1994). Case study research: Design and methods (2nd ed.). Sage Publications, Thousand Oaks, CA. 